\title{
Indications for incisional hernia repair: an international questionnaire among hernia surgeons
}

\author{
J. Nieuwenhuizen · G. J. Kleinrensink - W. C. J. Hop • \\ J. Jeekel · J. F. Lange
}

Received: 25 September 2007 / Accepted: 23 November 2007 / Published online: 18 December 2007

(C) Springer-Verlag 2007

\begin{abstract}
Background Incisional hernia repair can be a significant challenge for both surgeon and patient. Despite the growing amount of literature describing various methods of surgical techniques, little has been published regarding the natural course of incisional hernia and the opinions about indications for incisional hernia repair.

Methods A questionnaire was sent to a group of surgeons internationally renowned in incisional hernia surgery and research.

Results Pain and limitations of daily activities were considered the most important indications for repair. Cosmetic complaints were seen as least important. About $23 \%$ of patients were asymptomatic. More than $20 \%$ did not receive surgical treatment.

Conclusions A large proportion of patients with incisional hernia is not operated. Despite this large group of patients, valid data describing the natural course are absent. A prospective trial monitoring incisional untreated hernias as well as comparing conservative treatment with repair should be performed.
\end{abstract}

Keywords Hernia $\cdot$ Ventral $\cdot$ Repair

\section{Introduction}

During the past few decades, research on incisional hernia has focused on the development of different treatments and techniques. This has dramatically changed the outcome of

J. Nieuwenhuizen · G. J. Kleinrensink · W. C. J. Hop ·

J. Jeekel · J. F. Lange ( $\square)$

Department of Surgery, Erasmus University Medical Centre,

P.O. Box 2040, 10M, 3000 CA Rotterdam, The Netherlands

e-mail: j.lange@erasmusmc.nl this condition, traditionally highly prone to recurrences. Despite these improvements, the results of incisional hernia repair can be disappointing, with recurrences reported in up to $63 \%$ after primary repair and $32 \%$ after mesh repair, although lower incidences have been reported [1,2].

Very little data are available describing the natural course or indications for repair of incisional hernia. To our knowledge, only Courtney et al. described the symptoms and reasons for repair in a small group of incisional hernia patients [3]. Our own experience is that many incisional hernias are not operated on for various reasons, including comorbidity or expected failure of repair. In the literature however, valid information on how many patients do not receive surgical correction, including reasons for nonsurgical treatment, is absent.

In inguinal hernia surgery, observation ("watchful waiting") has become a realistic option for asymptomatic patients $[4,5]$. Strangulated hernias are rare, and postoperative, sometimes chronic, pain can impair patients' quality of life compared with observation. A mere inguinal hernia is no longer a solid indication for correction, and indication for repair has shifted from all inguinal hernia to symptomatic inguinal hernia alone. In incisional hernia, this practice might already have been common for many years, however, without any scientific evidence.

The aim of this questionnaire was to inventory opinions of internationally well-known hernia surgeons on the indications for incisional hernia repair and to estimate the amount of patients who do not receive surgical correction.

\section{Methods}

A Medline search was performed to find conditions in patients with hernia that were mentioned to be an indication 
Table 1 Number of patients: asymptomatic and acute incarceration

\begin{tabular}{lll}
\hline Question & Average & Range \\
\hline New patients last year & 101 & $10-600$ \\
Asymptomatic patients & $23 \%$ & $0-50 \%$ \\
Repairs & 78 & $10-556$ \\
No surgical treatment & $22 \%$ & $0-50$ \\
Acute incarceration & $6 \%$ & $0-30 \%$ \\
\hline
\end{tabular}

for repair. This included symptoms mentioned by the patient or conditions mentioned by the surgeon. The questionnaire was sent by e-mail to 70 surgeons specialized in hernia surgery and active in the field of hernia research, of whom $36(51 \%)$ responded. The questionnaire consisted of two parts. The first part comprised five questions (see Table 1). The surgeons were asked how many patients they had seen in their outpatient clinic. If no exact numbers were at hand, estimations were asked for. Reasons for refraining from surgical intervention were also requested.

1. Can you give an estimation of the number of new incisional hernia patients that visited your outpatient clinic last year?

2. Can you give an estimation of how many of these patients were asymptomatic at presentation?

3. Can you give an estimation of the number of incisional hernia repairs in your clinic last year?

4. Can you give an estimation of how many patients did not receive surgical repair (e.g., conservative treatment)?

5. Can you give an estimation of how many patients were operated for acute incarceration or strangulation?

The second part of the questionnaire consisted of a table in which an opinion was asked about nine different indications for repair (Table 2). Subjects were asked to rate their opinions on these indications from 1-5. An extra possibility was present to propose additional operation indications.

Statistical analysis was performed using Wilcoxon's signed ranks test.

\section{Results}

Results of the questionnaire are listed in Tables 1, 2 and 3.

The average number of new patients seen in the outpatient clinic was 98 . At presentation $23 \%$ were asymptomatic. On average 80 patients were operated each year, and the surgeons estimated that $22 \%$ of patients did not receive surgical correction of their incisional hernia (Table 1). Of all patients presenting with incisional hernia, $6 \%$ were operated for acute incarceration or strangulation. The main reasons for observational treatment were obesity, asymptomatic hernias, and comorbidity (Table 3 ).

Limitation of daily activities and pain were considered the most important reasons to surgically correct incisional

Table 3 Reasons not to operate

\begin{tabular}{ll}
\hline Reasons & Times mentioned \\
\hline Comorbidity, high operation risk & 19 \\
Asymptomatic & 10 \\
High body mass index or obesity & 5 \\
High age & 3 \\
Large size & 2 \\
Smoking & 1 \\
No progression & 1 \\
Loss of abdominal wall tissue & 1 \\
Small hernia & 1 \\
\hline
\end{tabular}

Table 2 Indications for repair

\begin{tabular}{|c|c|c|c|c|c|c|c|c|c|c|}
\hline Indication & Average & Pain & $\begin{array}{l}\text { Limitations } \\
\text { of daily } \\
\text { activities }\end{array}$ & $\begin{array}{l}\text { (Possible) } \\
\text { period } \\
\text { of incarceration }\end{array}$ & $\begin{array}{l}\text { Progressive } \\
\text { enlargement }\end{array}$ & $\begin{array}{l}\text { Risk of } \\
\text { incarceration }\end{array}$ & $\begin{array}{l}\text { Respiratory } \\
\text { dysfunction }\end{array}$ & $\begin{array}{l}\text { Discomfort } \\
\text { (no pain or } \\
\text { limitation) }\end{array}$ & $\begin{array}{l}\text { Young } \\
\text { age }\end{array}$ & $\begin{array}{l}\text { Only } \\
\text { cosmetic } \\
\text { complaints }\end{array}$ \\
\hline Pain & 1.4 & - & NS & NS & NS & NS & $P<0.05$ & $P<0.05$ & $P<0.05$ & $P<0.05$ \\
\hline $\begin{array}{l}\text { Limitations of } \\
\text { daily activities }\end{array}$ & 1.4 & NS & - & NS & NS & NS & $P<0.05$ & $P<0.05$ & $P<0.05$ & $P<0.05$ \\
\hline $\begin{array}{l}\text { (Possible) period of } \\
\text { incarceration }\end{array}$ & 1.6 & NS & NS & - & NS & NS & NS & NS & $P<0.05$ & $P<0.05$ \\
\hline Progressive enlargement & 1.7 & NS & NS & NS & - & NS & NS & NS & NS & $P<0.05$ \\
\hline Risk of incarceration & 1.7 & NS & NS & NS & NS & - & NS & NS & NS & $P<0.05$ \\
\hline Respiratory dysfunction* & 2.0 & $P<0.05$ & $P<0.05$ & NS & NS & NS & - & NS & NS & $P<0.05$ \\
\hline $\begin{array}{l}\text { Discomfort } \\
\quad \text { (no pain or limitation) }\end{array}$ & 2.1 & $P<0.05$ & $P<0.05$ & NS & NS & NS & $P<0.05$ & - & $P<0.05$ & $P<0.05$ \\
\hline Young age & 2.1 & $P<0.05$ & $P<0.05$ & $P<0.05$ & NS & NS & NS & NS & - & $P<0.05$ \\
\hline Only cosmetic complaints & 2.7 & $P<0.05$ & $P<0.05$ & $P<0.05$ & $P<0.05$ & $P<0.05$ & $P<0.05$ & $P<0.05$ & $P<0.05$ & - \\
\hline
\end{tabular}

NS not significant 
hernia (Table 2). Participating surgeons reported an average of 1.4 each. This differed significantly compared with cosmetic complaints, discomfort, respiratory dysfunction, and young age $(P<0.05)$. Cosmetic complaints and discomfort were considered the least important indications for repair, with an average of 2.7 and 2.1, respectively. Additional indications given were skin problems, loss of domain, fistula, and stiff mesh (in case of recurrence after mesh repair).

\section{Discussion}

There was a large variation in the number of asymptomatic patients between the patient populations of the respondents. However, the average of $25 \%$ is relevant because it is one of the first reported figures estimating the number of asymptomatic incisional hernias. The absence of symptoms was most often mentioned as a primary reason not to operate. One surgeon stated that there is no place for conservative treatment for incisional hernia. He was the only respondent who operated $100 \%$ of patients. On average, more than $20 \%$ of patients did not receive surgical repair of their incisional hernia. This would mean that many patients with incisional hernia are presumably monitored, although data about the natural course of incisional hernia has not been sufficiently recorded or published.

The number of patients operated for acute incarcerated hernia was low; about 5\%. Not all patients with incisional hernia consult their general practitioner or a surgeon. The total cohort of patients having a sometimes asymptomatic incisional hernia might be significantly larger, making the absolute risk for acute incarceration much lower. Predicting factors for acute incarceration have not been published, but 20 respondents rated incarceration risk as a valid indication for operation.

Discomfort and cosmetic complaints were considered the least valid indications for repair. Only one respondent rated cosmetic complaints as an indication for repair. Incisional hernia surgery can be extensive, with high complication rates. In a large proportion of patients, surgery will not generate better cosmetic results [2].

This internationally posted questionnaire shows that there is quite a uniform opinion about indications for repair and, more importantly, indications not to intervene surgically. However, when such a large proportion of patients is not operated for incisional hernia, data describing the natural course should be at hand. Prospectively monitoring patients not receiving incisional hernia repair would provide valuable information and should be performed.

Acknowledgments The authors thank all responding surgeons who took the time to fill in this questionnaire: G. Arlt, J.M. Bellón, D.H. Berger, R.P. Bleichrodt, G. Campanelli, M.A. Carlson, G. Champault, A. Ceydeli, P.K. Chowbey, J. Conze, M. Deysine, G.S. Ferzli, A. Fingerhut, R.J. Fitzgibbons, M.G. Franz, T. Franzén, S. Haapaniemi, B.M. Hansson, L.A. Israelsson, L.N. Jorgensen, H. Kehlet, A.N. Kingsnorth, U. Klinge, J.F. Lange, K.A. LeBlanc, Milo, Sair, M. Miserez, S.J. Nixon, P.J. O'dwyer, C. Peiper, M.G. Sarr, E. Schippers, R. Schwab, G.R. Voeller.

\section{References}

1. Burger JW, Luijendijk RW, Hop WC, Halm JA, Verdaasdonk EG, Jeekel J (2004) Long-term follow-up of a randomized controlled trial of suture versus mesh repair of incisional hernia. Ann Surg 240:578-583 (discussion 583-575)

2. Luijendijk RW, Hop WC, van den Tol MP, de Lange DC, Braaksma MM, JN IJ, Boelhouwer RU, de Vries BC, Salu MK, Wereldsma JC, Bruijninckx CM, Jeekel J (2000) A comparison of suture repair with mesh repair for incisional hernia. N Engl J Med 343:392-398

3. Courtney CA, Lee AC, Wilson C, O'Dwyer PJ (2003) Ventral hernia repair: a study of current practice. Hernia 7:44-46

4. Fitzgibbons RJ Jr., Giobbie-Hurder A, Gibbs JO, Dunlop DD, Reda DJ, McCarthy M Jr., Neumayer LA, Barkun JS, Hoehn JL, Murphy JT, Sarosi GA Jr., Syme WC, Thompson JS, Wang J, Jonasson O (2006) Watchful waiting vs repair of inguinal hernia in minimally symptomatic men: a randomized clinical trial. Jama 295:285-292

5. O'Dwyer PJ, Norrie J, Alani A, Walker A, Duffy F, Horgan P (2006) Observation or operation for patients with an asymptomatic inguinal hernia: a randomized clinical trial. Ann Surg 244:167-173 